\title{
FORMATION OF FOREIGN LANGUAGE COMPETENCE OF FUTURE ECONOMISTS BY MEANS OF DISTANCE LEARNING SYSTEM "MOODLE"
}

Summary. The study deals with formation of foreign language competence of future economists by means of distance learning system «MOODLE». It was stated that MOODLE focuses on collaborative learning technologies. The main feautres of this platform were described. It should be noted that MOODLE was created on the bases of five principles that were used by the creator of the platform Martin Dougiamas. The main advantages for tutors and students were described.

Keywords: informational communicative technologies, distance learning system, collaborative technology, advantages, multimedia.

Чернявський Б.Р.

Запорізький національний університет

\section{ФОРМУВАННЯ ІНШОМОВНОЇ КОМПЕТЕНТНОСТІ МАЙБУТНІХ ЕКОНОМІСТІВ ЗАСОБАМИ СИСТЕМИ ДИСТАНЦЙНОГО НАВЧАННЯ «МООDLЕ»}

\begin{abstract}
Анотація. Статтю присвячено формуванню іншомовної компетентності майбутніх економістів засобами системи дистанщійного навчання «MOODLE». Було зазначено, що платформа MOODLE орієнтована на колаборативні технології навчання. Описано основні особливості ціеї платформи. Слід зазначити, що MOODLE був створений на основі п'яти принципів, якими користувався розробник платформи Martin Dougiamas. Описано основні переваги для викладачів та студентів.
\end{abstract}

Ключові слова: інформаційно-комунікаційні технології, система дистанційного навчання, колаборативні технології, переваги, мультимедіа.

The main purpose of higher professional ed1 ucation system is to educate competitive specialists and create conditions for the formation of professional qualities and personality development that can adapt to modern social and economic transformations, which implies the development of flexible qualities of economists, including the ability to self-educate, self-assess and self-regulate.

Problem statement. The system of higher education as a source of educating highly skilled specialists must take into account new features of the employment field and educate graduates for such a workplace, where initiative, ability to see, formulate and solve professional tasks correctly are highly valued alongside with highlighting professionally relevant information in the vast information flow and making decisions on the basis of reliable information analysis. The need for lifelong learning exists due to the intensive development of tech and technology, the expansion of international cooperation and the emergence of globalization processes, which requires specialists to have good mastery of foreign language competence. That is why language education obtains particular relevance for future economists, and issues related to the methods and quality of education are prime for tutors.

Statement of the basic material. The system of foreign language competence formation is constantly changing, modern life is very dynamic and dictates the same high and at the same time effective learning pace, therefore the use of information and communication technologies (ICT) in the formation of foreign language competence is a very relevant issue of modern education. ICT are widely used as a simulator in world practice of the formation of foreign language competence of future economists for a long time. The well-known foreign technology, implying learning a foreign language with computer support, in the methodical literature is named Computer Assisted Language Learning (CALL).

The implementation of multimedia tools in the formation of foreign language competence has expanded the range of language training opportunities. Multimedia systems and methods of integrated application of software were appeared, in which the application of ICT becomes complex due to embedding various text materials, functions, options into a single system [2]. In spite of the fact that modern technological opportunities provide very significant means for teaching, at the same time programs that meet the quality standards of education have not been developed enough. One of the main reasons is the insufficient attention of developers to the linguistic and methodological requirements that educational materials must meet in a computer-mediated environment.

The interface should serve as a special teaching function in the software for the formation of foreign language competence. One of the methodological requirements for the interface is the use of the target language. When learning, A language is at the same time a purpose of learning and a means of interaction during education process. Therefore, it is recommended to apply the language for $100 \%$ during training tasks fulfilling for maximum immersion into the environment in order to obtain automaticity skill. Since the interface of the software serves as a means of interaction with the student, the language which is being studied must be presented in the interface very consistently: from the names of menu items, the wording of tasks, instructions for working with the software to the assessment of the student's actions, both in text and in audio format. It should be noted that the choice of 
the interface is one of the most difficult and crucial tasks. The software should not contain distracting elements, all the attention of the student should be focused only on the material. It can be stated that it is not possible to learn a foreign language only with the help of such electronic textbooks. It is rather an assistant, consultant or examiner, than an express language learning method [1].

Let us consider a sample of a modular object-oriented dynamic learning environment (MOODLE) which focuses on collaborative learning technologies. It allows to organize education in the process of common solving learning issues and to exchange knowledge. Various electronic and information resources were used in the process of foreign language competence formation before the transition to the MOODLE system. They served as tools for organizing students' independent work. However, the creation of educational materials using ICT and the use of automated means of implementing and displaying materials in an individual mode did not ensure effective interaction between the tutor and the student.

The feedback from participants of the educational process is one of the strengths of MOODLE. The system supports the exchange of files of any format - both between the tutor and the student, and between the students themselves. The mailing service allows to inform promptly all participants of the course or individual groups about current events. The forums technology makes it possible to organize an educational discussion of issues, and the debate can be conducted both in groups and with all participants of the course. You can attach files of any format to forum messages. The system is equipped with a message evaluation function. It can be done both by tutors and students. Chat allows to organize an educational discussion of issues in real time. Services "Messaging", "Comment" are intended for individual communication of the tutor and the student, which may involve reviewing the work, discussing individual educational questions.

This platform was created by Martin Dougiamas (ideologist and project manager for the development of the MOODLE learning management system) at Perth University of Technology in Australia. Since its creation, it is considered as an open, free software product with an easy and intuitive interface and accessible to everyone. The core for creating a learning management system was based on principles from a large number of works by such scientists as Lev Vygotsky, John Dewey, Jean Piaget, Ernst von Glaserfeld. Constructivism and social constructivism in the fields of education and psychology have been developed due to their scientific research [1].

Based on these areas, Martin Dougiamas formulated five principles underlying the system, combining them under the common name "social constructivism" [2]. These principles include: transition of the tutor to a new level of relations with students; learning in action; monitoring the activities of others; self-realization and self-presentation; variability and adaptability of the system.

The principle of the tutors's transition to a new level of relations with students: in a real educational environment, we are all potential tutors and students at the same time. This prin- ciple implies the tutor's transition to a new level of relations with students. He becomes more like a "guide» rather then a "medium of knowledge", directing them to an independent way of searching for information.

The principle of learning in action: we learn especially well when we create or try to explain something to other people. The basis is a rather obvious thesis that people learn in action. If the results of activities become available to other participants, then personal responsibility increases, more time is spent on self-examination and reflection, which greatly improves learning.

The principle of monitoring the activities of others: a great contribution to learning is made by monitoring the activities of our colleagues. The actions performed by other students in a similar learning situation have a significant impact on the activities of all participants in the educational process, provide food for thought, analysis, and involuntarily work in a general mode.

The principle of self-realization and self-presentation: understanding other people will allow them to be taught more individually. It is necessary to provide as many opportunities as possible for self-realization and self-presentation of students, as well as for analyzing the information provided by the student about himself/herself and his/her activity in the system.

The principle of variability and adaptability of the system: the learning environment must be flexible, providing participants of the educational process with a simple tool for implementing their learning needs. The system should be comprehensible and convenient for all participants in the educational process and provide them with various ways and means to solve training tasks: obtaining information, exchanging opinions, getting advice, evaluating, promptly updating, etc. Taking into account these principles, all the tools of the system MOODLE were implemented: communicative, educational and administrative [5].

This approach is especially attractive when studying dynamic, rapidly developing disciplines that require regular training, when it is important to give students not only some canonical information about the object of study, but also to acquaint them with the latest publications and fresh information on the subject being studied, to exchange views. Using MOODLE allows extensive use of training testing, to carry out pre-test and laboratory work. In addition, through forums or personal messages, students can consult with a teacher on issues of interest to them. Such an approach is also very convenient for students, since it allows them to significantly save time and effort, to realize an individual approach during training.

There are a number of advantages in using MOODLE for students: work with content easily, optimization of educational time; availability of education at any convenient time from anywhere in the user's location; lack of problems with the acquisition of educational materials and manuals (the student gets access to a set of necessary educational materials in a modern electronic form directly from the programs of the learning environment); knowledge assessment system (electronic tests) is objective and independent from the tutor; active 
communication in the group; individualization and differentiation of the learning process; providing feedback to the teacher; creative and intellectual potential increases due to self-organization, striving for knowledge, ability to interact with computer equipment and mastering the latest information technologies.

In addition to the benefits for students, there are pros for tutors: the ability to automate the knowledge assessment system; the use of modern multimedia technologies in educational materials, which is not always possible in the classroom; synchronous or asynchronous communication of students with each other and with the tutor; rapid sharing of information among users and analysis of the database of the course participants' activities is carried out remotely; simplified process for downloading informative educational information, assignments and course updates. Synchronous communication can be implemented using video conferencing, and asynchronous involves electronic correspondence. Thus, the interaction of the tutor with the audience of the "listeners" of the course is preserved.

Conclusions from this study. In general, working with the MOODLE platform allows you to optimize the educational process during formation of foreign language competence, to involve students in the process of live communication; to develop independence for finding, retrieving, evaluating and analyzing information, which contributes to the formation of students' professional and communicative skills.

\section{References:}

1. Bovtenko M.A. Lingvometricheskaya otsenka obuchayushchikh programm po inostrannomu yazyku // ITO-2000. - M., 2000. - P. 35-40.

2. Marchenko E.V. Metodicheskie osnovy obucheniya fonetike angliiskogo yazyka s pomoshch'yu komp'yuternykh tekhnologii // Vestnik Moskovskogo gosudarstvennogo gumanitarnogo universiteta im. M.A. Sholokhova. Filologicheskie nauki. - 2009. - No 2. - P. 52-58.

3. Dougiamas M.A. Journey into Constructivism. 1998. URL: http://dougiamas.com/writing/constructivism.html (дата обращения 01.10.2011).

4. Philosophy of Moodle, Moodle: open-source community-based tools for learning. 2011. URL: http://docs.moodle.org/21/ en/Philosophy (дата обращения 01.10.2011).

5. Pedagogy of Moodle, Moodle: open-source community-based tools for learning. 2011. URL: http://docs.moodle.org/21/ en/Pedagogy (дата обращения 01.10.2011). 